2 Composite Material

\title{
Hydrogen Bonds of Sodium Alginate/Antarctic Krill Protein
}

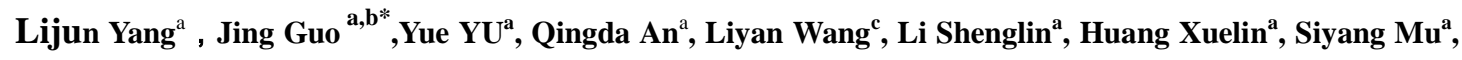 \\ Shanwei Qi ${ }^{\mathrm{a}}$ \\ ${ }^{a}$ Dalian Ploytechnic University, Liaoning 116034, P.R. China \\ ${ }^{\mathrm{b}}$ Liaoning Engineering Technology Research Center of Function Fiber and its Composites, Dalian Ploytechnic \\ university, Dalian 116034, P.R. China \\ ${ }^{\mathrm{c}}$ Shenyang university of technology, Liaoning 111003, P.R. China \\ Correspondence to: J. Guo (E-mail: guojing8161@163.com)
}

\begin{abstract}
Sodium alginate/Antarctic Krill protein composite material (SA/AKP) was successfully obtained by blending method. The hydrogen bonds of SA/AKP composite material were analyzed by Fourier transform infrared spectroscopy (FT-IR) and Nuclear magnetic resonance hydrogen spectrum (HNMR). Experiment manifested the existence of intermolecular and intramolecular hydrogen bonds in SA/AKP system; strength of intermolecular hydrogen bond enhanced with the increase of AKP in the composite material and the interaction strength of hydrogen bonding followed the order: $\mathrm{OH}$...Ether $\mathrm{O}>\mathrm{OH} \ldots \pi>\mathrm{OH} . . \mathrm{N}$. The percentage of intermolecular hydrogen bond decreased with increase of $\mathrm{pH}$. At the same time, the effect of hydrogen bonds on properties of the composite material was discussed. The increase of intermolecular hydrogen bonding led to the decrease of crystallinity, increase of apparent viscosity and surface tension, as well as obvious decrease of heat resistance of SA/AKP composite material. SA/AKP fiber SEM images and energy spectrum showed that crystallized salt was separated from the fiber, which possibly led to the fibrillation of the composite fibers.
\end{abstract}

Key words: sodium alginate; the Antarctic krill protein; hydrogen bond; derivative infrared spectra; composite fiber

\section{Introduction}

As oil resources become scarcer, high consumption and pollution of synthetic fiber production is facing huge market pressure. Production of biodegradable fiber has been becoming currently a hot issue (Chang, Duan, Cai, \& Zhang, 2010; Zhou, Ma, Shi, Yang, \& Nie, 2011; Yang, Ma, \& Guo, 2011). Regenerative materials have been the new orientation of the development of new materials since environmental protection attracted global attention for decades. Algae, as a kind of renewable biomass resources, has been widely exploited in medicine, modern food industry, spinning and weaving (Khan, Huq, Saha, Khan, \& Khan, 2010; Senthil Kumar, 2013;

\footnotetext{
* Corresponding authors. Tel:13704091879.

E-mail address: guojing8161@163.com
} 
Pontrandolfo, \& Pujari, 2013; Faqeer, 2014). Alginates are a family of linear unbranched polysaccharides which contain varying amounts of 1, 4'-linked $\beta$-D-mannuronic acid and $\alpha$-L-guluronic acid residues. The residues may vary widely in composition and sequence and are arranged in a pattern of blocks along the chain. These homopolymeric regions of $\beta$-D-mannuronic acid blocks and $\alpha$-L-guluronic acid blocks are inter-dispersed with regions of alternating structure ( $\beta$-D-mannuronic acid- $\alpha$-L-guluronic acid blocks) (Khan \& Ahmad, 2013; Lee et al., 2007; Turco et al., 2011). It is easy to form hydrogels by chelating with calcium and other divalent metal ions (Woraharn, Chaiyasut, Sirithunyalug, \& Sirithunyalug, 2010; Murakamiet et al., 2010). The molecular structure of the algae is similar to cellulose containing large number of hydroxyl groups. There are intra/intermolecular hydrogen bonds in sodium alginate, which lead to stronger interaction forces. (Park, Chang, Jeong, \& Hyun, 2013; Isogai, Saito, \&Fukuzumi, 2011).

Antarctic krill protein (AKP) is also a kind of renewable biomass resources from ocean. Antarctic krill biomass storage is nearly 6.5 10 billion tons (Hewitt et al., 2010; Oehlenschl et al., 1982; Gigliotti et al., 2011 ). But thinking that antarctic krill can not be directly used for human consumption due to its high fluorine content (Soevik \& Braekkan, 1979; Varshal, Savinova \& Sedykh 1983), krill resources have not been fully exploited as yet. At present, the development and research on Antarctic krill resources mainly focus on the Antarctic krill oil, health care products, spices, animal feed and feed additive products (Tillander et al. 2014; Bax et al., 2012). AKP is rich in hydrogen bond donors and acceptors, such as nitrogen atoms, ether oxygen from protein and benzene ring from phenylalanine, which can form hydrogen bonds with hydroxyl groups in algae. AKP can exist in amphoteric aqueous solution and is sensitive to $\mathrm{pH}$, and there are large number of hydroxyl groups in sodium alginate molecules. Therefore, it is reasonable to infer that there are complex interactions in SA/AKP blending system. Guo .J et al. has prepared SA/AKP composite fiber through wet spinning technology (Jing., et al. 2013). Moreover, polyacrylonitrile-Graft-Antarctic Krill Protein nanofibers has also been successfully prepared via electrospun (Jing Guo et al. 2015). The results showed that in the preparation process SA was $5 \%$ in concentration . The cross-section of SA/AKP fiber has a jagged shape. Thermal property of SA/AKP fibers is similar to SA fibers. But, there is relatively little research on the effects of SA/AKP molecular interactions on material performance. Our research focused on the weak force of hydrogen bonding. In this work, the types of hydrogen bonds in SA/AKP composite material were first studied and then the relationship between the type of hydrogen bonds and properties of SA/AKP composite material was identified. We can change the hydrogen bond intensity to improve the performance of the material by adjusting the amount of AKP and the $\mathrm{pH}$ of the system. The experimental results could provide theoretical basis for the research and development of SA/AKP green composite fiber.

\section{Experimental and method}

\subsection{Materials}


Sodium alginate with molecular weight of $3 \times 10^{6} \sim 5 \times 10^{6}$ was obtained from Qingdao Bright Moon Seaweed Group Co., Ltd, China. Antarctic krill protein was prepared via extraction in alkali solution. Hydrochloric acid and sodium hydroxide were analytical grade, from Tianjin Ruimingte Chemicals Co., Ltd.

\subsection{Preparation of SA/AKP composite materials and fiber}

The AKP solution was prepared via putting AKP into $0.5 \%(\mathrm{w} / \mathrm{w})$ sodium hydroxide solution at $60{ }^{\circ} \mathrm{C}$ in a water bath, heating and stirring for $1 \mathrm{~h}$, then adjusting solution $\mathrm{pH}$ on a pHS-3C pH Meter (Shanghai scientific instrument co., Ltd., China). The SA was added into AKP solution under mechanical agitation, afterward, air bubbles were eliminated under vacuum condition for $24 \mathrm{~h}$. By this method, SA/AKP solutions with the ratios of $10 / 0,10 / 1,10 / 2$ and 10/3 (w/w) were prepared, and SA/AKP solutions with different $\mathrm{pH}$ values (i.e. $6 ; 7 ; 8 ; 9)$ were obtained at the SA/AKP ratio of 10/2 (w/w). The SA/AKP composite fiber was prepared successfully via wet-spinning method, and The SA/AKP solution was extruded to the $5 \%(\mathrm{w} / \mathrm{w})$ calcium chloride coagulation bath through spinnerets. Then SA/AKP composite fibers were obtained after stretching, washing and winding.

\subsection{Characterization of SA/AKP composite materials}

The morphology of the SA/AKP composites at different $\mathrm{pH}$ conditions was captured using a scanning electron microscope (SEM) (S-4800, HITACHI, Japan) at the accelerating voltage of $10 \mathrm{kv}$ after sputter-coating with Au. The atomic composition analysis of the SA/AKP composites at different $\mathrm{pH}$ conditions was carried out by energy-dispersive X-ray spectroscopy (EDX) adjunct to the SEM.

The Nuclear Magnetic Resonance (NMR) spectra were recorded using an AC 400 instrument (Bruker, Switzerland) in deuterated water $\left(\mathrm{D}_{2} \mathrm{O}\right)$ at room temperature for chemical structure of SA/AKP materials. Interaction forces of the SA/AKP sample was confirmed by a Nicolet 470 fourier-transformed infrared spectroscope (FTIR), The $\mathrm{KBr}$ pressed disc technique was used for SA/AKP sample preparation. The scanning range was $4500-400 \mathrm{~cm}^{-1}$ with 64 scans at a resolution of $4 \mathrm{~cm}^{-1}$. Hydrogen bonding strength was taken via six times infrared spectrum fitting operation, and the standard deviation was calculated by following formula.

$$
\sigma=\sqrt{\frac{\sum_{i=1}^{n}\left(x_{i}-\bar{x}\right)^{2}}{n-1}}
$$

where, $\sigma$ : Standard deviation; $x_{i}$ : The Nth time fitting peak area; $\bar{x}$ : Average peak area; n: Measurement times

The thermal properties of composite material were measured using thermogravimetric analysis (TGA-50, Shimadzu, Japan) and 200F3 differential scanning calorimeter DSC (NETZSCH, Germany) which was carried out in $\mathrm{N}_{2}$ atmosphere from 0 to $300^{\circ} \mathrm{C}$ heated at a rate of $10^{\circ} \mathrm{C} / \mathrm{min}$. TGA analysis of all the samples were carried out using crimped aluminum pans from the ambient temperature to $700^{\circ} \mathrm{C}$ in $\mathrm{N}_{2}$ flow at a heating rate of $10^{\circ} \mathrm{C} / \mathrm{min}$.

The Crystal structure of the SA/AKP composites was determined using an X-ray diffractometer (XRD, DIFFRACTOMETER-6000, Japan) with $\mathrm{Cu} \mathrm{K} \alpha$ over a $2 \theta$ range $5-80^{\circ}$ with a step size of $4 \% \mathrm{~min}$. Tube voltage is $2.5-40 \mathrm{kv}$. Tube current is $80 \mathrm{~mA}$. 
The rheological properties of the SA/AKP blend solution were studied by digital rotational viscometer (DV-C, BROOKFILED, USA). Test conditions: $40^{\circ} \mathrm{C}, 12-100$ RPM. Surface tension test were applied on Sigma 700 Surface tensiometer (Finland).

\section{Results and discussion}

\subsection{Hydrogen bond of SA/AKP composite material}

AKP was obtained via extraction in alkali solution according to literature (Jing, et al. 2013). The SA/AKP composite material was prepared successfully by direct blending in water. There are a lot of hydrogen bond donors and acceptors in AKP and SA. SA/AKP composite material was fabricated successfully based on intermolecular hydrogen bonding. Different types of hydrogen bonding such as $\mathrm{OH} \ldots \mathrm{OH}, \mathrm{OH} \ldots \pi$, $\mathrm{OH} \ldots \mathrm{N}, \mathrm{OH} \ldots$...ther $\mathrm{O},-\mathrm{OH}$ annular polymer, were formed in the composites. The ownership of different kinds of hydrogen bonding in the infrared spectrum was confirmed according to literature (Dagang et al., 2011; Painter et al., 1987; Chen et al., 1998).

The fourier-transformed infrared spectroscope of pure SA and AKP was shown in Fig. 1(a). Hydroxyl group of SA is commonly strong and observed at $3404 \mathrm{~cm}^{-1}$ at IR spectra. The peak at $1607 \mathrm{~cm}^{-1}$ is characteristic of the carbonyl group of SA. The peaks located at $1415 \mathrm{~cm}^{-1}$ and $1038 \mathrm{~cm}^{-1}$ in SA are $\mathrm{C}-\mathrm{H}$ bending vibration absorption and six-member ring stretching vibration absorption. The peak at $3410 \mathrm{~cm}^{-1}$ is clearly observed in infrared spectra of AKP which belongs to N-H and O-H stretching vibration absorption of the stack. Peaks located at $1645 \mathrm{~cm}^{-1}, 1527 \mathrm{~cm}^{-1}, 1388 \mathrm{~cm}^{-1}$ and $1238 \mathrm{~cm}^{-1}$ are characteristic of the amide group of protein. There is no new absorption peak in the SA/AKP composites with different mixed ratio in Fig. 1(b), which may be strong hydrogen bonding interaction between molecules of the composites. The broad peak around $3000-3700 \mathrm{~cm}^{-1}$ was smoothed using the Savitzky - Golay method by 15 points in Origin 8.0 under six times infrared spectrum fitting operation, with the average of the six times data and the standard deviation calculated. Different types of hydrogen bond were ensured by second derivative spectra shown in Fig. 1(c). As shown in Fig. 1(d-f) and Tab. 1, assignments, strength and child peak distribution of different types of hydrogen bonding in the broad peak from 3000 to $3700 \mathrm{~cm}^{-1}$ were based on Gaussian fitting. As shown in Tab. 1, the percentage of intermolecular hydrogen bond increases from $41.1 \%$ to $46.0 \%$ and percentage of intramolecular hydrogen bond reduces to $55.0 \%$ from $51.3 \%$. At the same time, the number of free hydroxyl is nearly unchanged. The data reported here suggest that the interaction between AKP and SA in the composite material is primarily intermolecular hydrogen bond, which is formed from destroyed intramolecular hydrogen bond not free hydroxyl. The interaction of hydroxyl $(\mathrm{OH} \ldots \mathrm{OH})$ played an important role in intramolecular hydrogen bonding, part of which was in the form of annular polymer. The contribution of various types of intermolecular hydrogen bond is $\mathrm{OH}$...Ether $\mathrm{O}>$ $\mathrm{OH} . . . \pi>\mathrm{OH} . . . \mathrm{N}$ from the data of Tab.1.

The HNMR spectrum of SA/AKP composite materials was shown in Fig.1 (g) \& (h). It was found that obvious peaks at 3.7-4.0 ppm were attributed to in the sodium alginate backbone in Fig. 1(g). Complex molecular structure leads to the existence of 
many peaks in the HNMR spectrum of AKP, protons of $-\mathrm{CH}_{3}$ and $-\mathrm{CH}_{2}$ respectively appearing at $0.9 \mathrm{ppm}$ and $1.2 \mathrm{ppm}$, other weak characteristic peaks at $1.8-3.2 \mathrm{ppm}$ and 6.5-8.0 ppm. Compared with SA and AKP HNMR spectrum, SA/AKP don't have new peaks, which means that there is no reaction in blend. But, characteristic peak Chemical shift of AKP have regular migration when AKP added content increase in Fig. 1(h). This powerful responded to the FTIR conclusion that the valid interaction was formed in SA/AKP blend system. Moreover, this interaction force led to regular migration more obvious as AKP content increase. HNMR spectrum was provided a proof for strong interaction exist in SA/AKP blend system and it is probably the hydrogen bond force.

\subsection{The influence of $\mathrm{pH}$ for hydrogen bonding in SA/AKP composite material}

According to the literature, electrostatic forces, hydrophobic force and hydrogen bonding are main forces between protein and polysaccharide (Zhang et al., 2014). It indicates that in aqueous dispersion, $\mathrm{pH}$ is an important factor which affects the protein and polysaccharide composite system. Because the surface charge of protein could be affected by $\mathrm{pH}$. The isoelectric point is one of the most important physicochemical properties of proteins. Proteins are amphoteric molecules, as average surface charge is zero, at the isoelectric point of protein. Proteins are prone to precipitate out at isoelectric point due to the minimum solubility of protein. The surface positive charge density increases when $\mathrm{pH}$ is less than the isoelectric point of protein. Otherwise, the negative charge density increases. SA is a kind of polysaccharide, which is also an electrolyte with a certain degree of ionization in the solution. Therefore, there may be an influence of $\mathrm{pH}$ on the SA/AKP composite material because both $\mathrm{AKP}$ and $\mathrm{SA}$ are sensitive to $\mathrm{pH}$.

The infrared and second derivative spectra of SA/AKP composite material at different $\mathrm{pH}$ were shown in Fig. 2(a) and 2(b). There is obvious change for the hydroxyl absorption peak at different $\mathrm{pH}$, which probably means that interaction force between SA and AKP molecular chain was influenced by the $\mathrm{pH}$. The broad peaks, from 3000 to $3700 \mathrm{~cm}^{-1}$, were performed through six times Gaussian fitting according to the absorption numbers of different types of hydrogen bonds. Assignments of different types of hydrogen bond, Gaussian fitting data and the standard deviation were shown in Fig. 2(c-f) and Tab. 2. Obvious change of absorption peaks strength of different type hydrogen bond was observed from Gaussian fitting data. These findings support the hypothesis that hydrogen bond types and strength were influenced by the $\mathrm{pH}$. Data show that the percentage of intermolecular hydrogen bonding was decreased with the increase of $\mathrm{pH}$. While there is an obvious contrary trend of intramolecular hydrogen bonding. Interaction of hydroxyl-hydroxyl is the major constituent of intramolecular hydrogen bonding. At the same time, interaction of hydroxyl and oxygen from ether is the major constituent of intermolecular hydrogen bonding. An exception is the interaction of $\mathrm{OH} . . \pi$ which takes the major constituent of intermolecular hydrogen bonding when $\mathrm{pH}$ is 9 . The reason for this exception is not clear from the study results.

\subsection{The influence of hydrogen bonding on crystallinity}


The experimental results showed that the crystallinity of SA/AKP composite material was affected by $\mathrm{pH}$. The crystallinity of SA/AKP composite material increases with the increase of intramolecular hydrogen bond, the crystallization of composite materials is mainly contributed by protein crystallization based on XRD results in Fig. 3 (a) and (b). XRD data shows that the maximum crystallinity signal of the SA/AKP composites appears at $\mathrm{pH}$ is 9 . This is probably attributed to the increase of intramolecular hydrogen bonding percentage, which makes molecular chain arrangement on the lattice in crystallization process easier.

\subsection{The influence of hydrogen bonding on heat stability}

The thermal stability of SA/AKP composite material was tested by thermogravimetric measurements (TGA). TGA studies demonstrated that the SA/AKP composite material is divided into four stages in Fig.3(c). The first peak of differential thermo-gravimetric curve is around $80{ }^{\circ} \mathrm{C}$ because of thermal degradation of AKP and loss of combined water. The maximum peak of thermal weight loss is around $230{ }^{\circ} \mathrm{C}$ because glycosidic bond breaking down into stable intermediate. The stable intermediate decomposition and carbonization is at $425^{\circ} \mathrm{C}$. Macromolecular backbone carbonation completes at $630{ }^{\circ} \mathrm{C}$ (Ping, et al., 2015). There is no significant effect on the thermal degradation process with different intermolecular hydrogen bond content. There are four stages of thermal degradation for all the samples. Comparing $\mathrm{pH}=6$ with $\mathrm{pH}=9$, the intramolecular hydrogen bond percentage increased from $52.5 \%$ to $57.8 \%$ based on Tab. 2. The maximum degradation rates at $\mathrm{pH}=6, \mathrm{pH}=7$ and $\mathrm{pH}=9$ have moved to lower temperature with intramolecular hydrogen bond content in enlarger view of figure in Fig. 3 (c). That at $\mathrm{pH}=7$ and $\mathrm{pH}=8$ have a same tendency. To study the influence of $\mathrm{pH}$ on maximum degradation rate tendency, DSC analysis technology was employed, and DSC curve is shown in Fig. 3 (d). There are wide endothermic peaks near $100^{\circ} \mathrm{C}$ due to moisture loss in the system. Obviously, exothermic peak is around $230{ }^{\circ} \mathrm{C}$, which contributes to glycosidic bond breaking down. At the same time, the significant phenomenon is that the maximum degradation rate tendency has moved to lower temperature with $\mathrm{pH}$ from 6 to 9. Therefore, we infer a consequence that the more percentage of intramolecular hydrogen bond is, the better heat resistance of the SA/AKP composites will be. The main reason may be that the increase of intramolecular hydrogen bonding leads to the increase of the degree of crystallinity since the melting of crystallization area will need more heat.

\subsection{The influence of hydrogen bonding on Liquidity}

Liquidity curve of SA/AKP composite material was illustrated in Fig. 3(e). It indicates that the SA/AKP composite solution can be regarded as a pseudoplastic fluid, and its viscosity decreases as the shear rate increases. The possible reason is that the conformation and interaction force of SA and AKP in solution is affected by $\mathrm{pH}$ variation. In order to prove our suppose of viscosity change reason, surface tension test as a supporting experiment was carried out and the surface tension test curve is shown in Fig. 3(f). Experimental data indicated that surface tension decreases with $\mathrm{pH}$ varying from 6 to 9 . It provides evidence that the interaction force decreases in the composite system as $\mathrm{pH}$ increases. SA and AKP as polyelectrolyte were sensitive to $\mathrm{pH}$. With $\mathrm{pH}$ increase, the negative charge of protein and SA increases on the surface, 
leading to the increase of electric repulsion between AKP and SA, and finally the decrease in viscosity. When $\mathrm{pH}$ is 6 , which is close to the isoelectric point of Antarctic krill protein, some high molecular weight proteins might start to precipitate and the composite material maybe appear slight phase separation, resulting in the much higher apparent viscosity of flow curve than the other samples under the same shear rate. According to our research, this interaction was hydrogen bond. So we probably have a consequence that viscosity decreases as the intermolecular hydrogen bond relative content reduces. Based on our research conclusion, in order to increase spinnability and improve production efficiency, we can change SA/AKP solution viscosity at high-concentration systems for wet spinning by adjusting the solution's $\mathrm{pH}$ value.

\subsection{The microstructure of SA/AKP composite fibers}

The SA/AKP composite fiber was prepared by SA/AKP composite solution by spinning dope. Morphology photos of fiber surface before and after the friction under scanning electron microscope were shown in Fig. 4(a \& b). SEM observation shows that there is regular uniformly groove structure that the width of the grooves is 2 microns along the axial on the surface of the fiber without friction, and the formation of this structure is attributed to that the double diffusion of solvents and solidifier leads to uneven shrink of the fiber in all directions in wet spinning processing. The groove structure can contribute to increase the hygroscopic of fiber during utilization. After friction, the surface of the fiber shows disordered burrs and the original regularly groove structure is damaged. The fact may be that, at solid state, the composite fiber is two phase coexistence, a two-continuous phase in the matrix due to the existence of strong hydrogen bond interaction between AKP and SA macromolecules. There are many island aggregates on continuous phase from Fig. 4(a \& b), and the EDX data of continuous phase and island phase in Tab. (3) and Tab. (4). There is less oxygen and more chlorine, sodium and calcium in island aggregation compared with the continuous phase. Therefore the major ingredient of island aggregation is solid crystal precipitation of $\mathrm{NaCl}$ and $\mathrm{CaCl}_{2}$. When $\mathrm{SA} / \mathrm{AKP}$ composite is in solid state, $\mathrm{NaCl}$ and $\mathrm{CaCl}_{2}$ arranges easily on the lattice for complete crystallization and precipitation. This is the possible reason for the presence of disordered burrs structure during the process of friction. Salt crystallization from the precipitation of the system might make the chains of macromolecular exfoliate to form split-phase fibrillation structures.

\section{Conclusions}

In summary, SA/AKP composite material has been successfully obtained by mixing directly. Type and percentage of inter/intramolecular hydrogen bonding of composite material was analyzed by FT-IR through Gaussian Fitting and HNMR. The interaction through intermolecular hydrogen bonding of two components increase with mixed ratio increasing. The percentage of intermolecular hydrogen bonding decreases with $\mathrm{pH}$ increasing from 6 to 9. The crystallization of composite material increases as intramolecular hydrogen bonding increasing, which also demonstrated by XRD. Viscosity and surface tension also decrease with the decrease of intermolecular hydrogen bond. SA/AKP composite fiber was prepared by SA/AKP composite 
solution for wet spinning dope. This composite fiber can be utilized as regenerative materials for application.

\section{Acknowledgments}

This research was supported by the National Science Foundation of China (51373027, LR2012017), National Science Foundation of Liaoning (2015020221), Dalian Polytechnic University and the center for analysis and test center, are gratefully acknowledged.

\section{Reference}

Bax, M. L., Aubry, L., Ferreira, C., Daudin, J. D., Gatellier, P., Remond, D., et al. (2012).Cooking temperature is a key determinant of in vitro meat protein digestion rate: Investigation of underlying mechanisms. Journal of Agriculture and Food Chemistry, 60, 2569-2576.

Chang, C. Y., Duan, B., Cai, J., \& Zhang, L. N. (2010). Superabsorbent hydrogels based on cellulose for smart swelling and controlled delivery. European Polymer Journal, 46, 92-100.

Chen, Ch., Xuemin, X., Jinsheng, G., Yongjie, Y. (1998) Type of hydrogen bonds in coal. Journal of fuel chemistry and technology, 2, 140-144.

Dagang, L., Xiaoyu, C., Yiying, Y., Mindong, C., Qinglin, W. (2011) Structure and rheology of nanocrystalline cellulose. Carbohydrate Polymers, 84, 316-322.

Dangelico, R. M., Pontrandolfo, P., \& Pujari, D. (2013). Developing sustainable newproducts in the textile and upholstered furniture industries: Role of exter-nal integrative capabilities. Journal of Product Innovation Management, 30(4), 642-658.

Faqeer, M. (2014). Emerging green technologies and environment friendly productsfor sustainable textiles. In Roadmap to sustainable textiles and clothing. Singapore: Springer.

Gigliotti, J. C., Davenport, M. P., Beamer, S. K. (2011) Extraction and characterisation of lipids from Antarctic krill ( Euphausia superba). Food Chemistry, 125,1028-1036.

Hewitt, P. P., Low, E. H. L. (2000) The fishery on Antarctic krill: Defining an ecosvstem approach to manage-ment. Reviews in Fisheries Science, 8, 235.

Isogai, A., Saito, T., \& Fukuzumi, H. (2011). TEMPO-oxidized cellulose nanofibers.Nanoscale, 3(1), 71-85.

Jing, G., Xuecai, Li., Yuyan, Zh., Li Zhang., et al.(2013). The study of rheological and mechanical properties of the Antarctic krill protein/sodium alginate fibers. Advanced Materials Research, 813, 377-381.

Jing, G., Siyang, M., Yuanfa, L., Yuyan, Zh., \& Sen, Zh.(2015). Thermal Properties of Electrospun Polyacrylonitrile-Graft-Antarctic Krill Protein. AATCC jounal of research, 2(4),14-19.

Khan, A., Huq, T., Saha, M., Khan, R. A., \& Khan, M. A. (2010). Surface modification of calcium alginate fibers with silane and methyl methacrylate monomers. Journal of Reinforced Plastics and Composites, 29, 3125-3132.

Khan, Ferdous, \& Ahmad, S. R. (2013). Polysaccharides and their derivatives for ver-satile tissue engineering application. Macromolecular Bioscience, 13(4), 395-421.

Lee, Y. J., Shin, D. S., Kwon, O. W., Park, W. H., Choi, H. G., Lee, Y. R., et al. (2007). Preparation of atactic poly (vinyl alcohol)/sodium alginate blendnanowebs by electrospinning. Journal of Applied Polymer Science, 106(2), 1337-1342.

Murakami, K., Aoki, H., Nakamura, S., Nakamura, S., Takikawa, M., Hanzawa, M., et al.(2010). 
Hydrogel blends of chitin/chitosan, fucoidan and alginate as healing-impaired wound dressings. Biomaterials, 31(1), 83-90.

Oehlenschl, G. J., Manthey, M. (1982). Fluoride content of Antarctic marine animals caught off Elephant Island. Pol Bio, 1, 125-127.

Park, M., Chang, H., Jeong, D. H., \& Hyun, J. (2013). Spatial deformation of nanocel-lulose hydrogel enhances SERS. Biochip Journal, 7(3), 234-241.

Painter, P. C., Sobkowiak, M., Youtchefft, J., (1987). FT-IR study of hydrogen bonding in coal, Fuel, 66, 973-978.

Ping, W., Benjamin, T., Anli, T., Chunxia, W., Liping, Zh., \& Shaohai, F. (2015). Properties of alginate fiber spun-dyed with fluorescent pigmentdispersion . Carbohydrate Polymers, 118 , 143-149.

Senthil Kumar, R., \& Vigneswaran, C. (2013). Textiles for industrial applications. BocaRaton, Florida, US: CRC Press.

Soevik, T., Braekkan, O. R. (1979). Fluoride in Antarctic Krill (Euphausia superba) and Atlantic Krill ( Meganyctiphanes norvegica). Fisheries Res Board Can, 1979, 36, 1414-1416.

Tillander, V., Bjrndal, B., Burri, L., Bohov, P., Skorve, J., Berge, R. K., et al. (2014). Fish oil and krill oil supplementations differentially regulate lipid catabolic and synthetic pathways in mice. Nutrition \& Metabolism, 11, 20-36.

Turco, G., Donati, I., Grassi, M., Marchioli, G., Lapasin, R., \& Paoletti, S. (2011).Mechanical spectroscopy and relaxometry on alginate hydrogels: A comparativeanalysis for structural characterization and network mesh size determination.Biomacromolecules, 12(4), 1272-1282.

Varshal, G., Savinova, E.,Sedykh, E., et al. (1983) Characterization of the mineral composition of isolated krill proteins. Food Nahrung, 27, 945-949.

Woraharn, S., Chaiyasut, C., Sirithunyalug, B., \& Sirithunyalug, J. (2010). Survival enhancement of probiotic Lactobacillus plantarum CMU-FP002 by granulation and encapsulation techniques. African Journal of Microbiology Research, 4, 2086-2093.

Yang, L. L., Ma, X. Y., \& Guo, N. N. (2011). Synthesis and properties of sodium alginate/Ne(+) rectorite grafted acrylic acid composite superabsorbent via (60) Cogamma irradiation. Carbohydrate Polymers, 85, 413-418.

Zhang, L., Xinhua, Z., Guoqiang, Y. Dongmei, Ch., Yingde, C. (2014) Preparation and Slow-R elease of Feather Keratin /Sodium Alginate Microspheres. Polymer materials Science and Engineering, 8,150-155.

Zhou, Y. S., Ma, G. P., Shi, S. Q., Yang, D. Z., \& Nie, J. (2011). Photopolymerized water-soluble chitosan-based hydrogel as potential use in tissue engineering. International Journal of Biological Macromolecules, 48, 408-413. 
Table.1 The fitting results of various kinds of hydrogen bonds

\begin{tabular}{|c|c|c|c|c|c|c|c|c|}
\hline Sample & $\begin{array}{c}\text { Hydrogen bon } \\
\text { type }\end{array}$ & & Abbreviations & $\begin{array}{l}\text { Wave number } \\
\qquad / \mathrm{cm}-1\end{array}$ & $\begin{array}{c}\text { Average } \\
\text { peak area }\end{array}$ & $\begin{array}{c}\text { Standard } \\
\text { deviations } \\
/ \%\end{array}$ & $\begin{array}{r}\text { Rel } \\
\text { stren }\end{array}$ & $\begin{array}{l}\text { tive } \\
\text { th } / \%\end{array}$ \\
\hline \multirow{6}{*}{$10 \mathrm{AKP}$} & free hydroxyl & I & $-\mathrm{OH}$ & 3595 & 7.01 & 2.71 & 2.4 & 2.4 \\
\hline & \multirow{2}{*}{$\begin{array}{l}\text { Intramolecular } \\
\text { hydrogen bond }\end{array}$} & III & $\mathrm{OH} \ldots \mathrm{OH}$ & 3409 & 131.35 & 0.72 & 44.2 & \multirow[b]{2}{*}{56.5} \\
\hline & & V & $\begin{array}{l}\text { annular } \\
\text { polymer }\end{array}$ & 3219 & 35.52 & 1.91 & 12.3 & \\
\hline & \multirow{3}{*}{$\begin{array}{l}\text { Intermolecular } \\
\text { hydrogen bond }\end{array}$} & II & $\mathrm{OH} \ldots \pi$ & 3522 & 42.29 & 4.71 & 13.7 & \multirow{3}{*}{41.1} \\
\hline & & IV & OH...ether $\mathrm{O}$ & 3295 & 52.13 & 1.86 & 18 & \\
\hline & & VI & $\mathrm{OH} \ldots \mathrm{N}$ & 3132 & 25.43 & 8.32 & 9.4 & \\
\hline \multirow{6}{*}{ 20AKP } & free hydroxyl & I & $-\mathrm{OH}$ & 3594 & 11.1 & 9.01 & 2.6 & 2.6 \\
\hline & \multirow{2}{*}{$\begin{array}{l}\text { Intramolecular } \\
\text { hydrogen bond }\end{array}$} & III & $\mathrm{OH} \ldots \mathrm{OH}$ & 3406 & 198.37 & 1.43 & 43.6 & \multirow[b]{2}{*}{55} \\
\hline & & V & $\begin{array}{l}\text { annular } \\
\text { polymer }\end{array}$ & 3214 & 54.39 & 3.47 & 11.4 & \\
\hline & \multirow{3}{*}{$\begin{array}{l}\text { Intermolecular } \\
\text { hydrogen bond }\end{array}$} & II & OH... $\pi$ & 3519 & 70.43 & 1.32 & 15.1 & \multirow{3}{*}{42.4} \\
\hline & & IV & $\mathrm{OH} \ldots$...ether $\mathrm{O}$ & 3292 & 89.2 & 1.23 & 19.6 & \\
\hline & & VI & $\mathrm{OH} \ldots \mathrm{N}$ & 3126 & 35.68 & 0.9 & 7.8 & \\
\hline \multirow{6}{*}{ 30AKP } & free hydroxyl & I & $-\mathrm{OH}$ & 3599 & 13.64 & 9.02 & 2.7 & 2.7 \\
\hline & \multirow{2}{*}{$\begin{array}{l}\text { Intramolecular } \\
\text { hydrogen bond }\end{array}$} & III & $\mathrm{OH} \ldots \mathrm{OH}$ & 3406 & 237.85 & 1.2 & 40.3 & \multirow[b]{2}{*}{51.3} \\
\hline & & V & $\begin{array}{l}\text { annular } \\
\text { polymer }\end{array}$ & 3215 & 64.17 & 1.61 & 10.9 & \\
\hline & \multirow{3}{*}{$\begin{array}{l}\text { Intermolecular } \\
\text { hydrogen bond }\end{array}$} & II & OH... & 3520 & 100.55 & 2.44 & 17.3 & \multirow{3}{*}{46} \\
\hline & & IV & $\mathrm{OH} \ldots$ ether $\mathrm{O}$ & 3293 & 113.68 & 7.05 & 20.4 & \\
\hline & & VI & $\mathrm{OH} \ldots \mathrm{N}$ & 3131 & 49.14 & 1.75 & 8.4 & \\
\hline
\end{tabular}


Table 2. The fitting results of various kinds of hydrogen bonds

\begin{tabular}{|c|c|c|c|c|c|c|c|c|}
\hline Sample & \multicolumn{2}{|l|}{$\begin{array}{l}\text { Hydrogen bond } \\
\text { type }\end{array}$} & Abbreviations & $\begin{array}{l}\text { Wave number } \\
\text { /cm-1 }\end{array}$ & $\begin{array}{l}\text { Average } \\
\text { peak area }\end{array}$ & $\begin{array}{c}\text { Standard } \\
\text { deviations } \\
\quad / \%\end{array}$ & \multicolumn{2}{|c|}{$\begin{array}{c}\text { Relative } \\
\text { strength } / \%\end{array}$} \\
\hline \multirow{5}{*}{$\mathrm{PH}=6$} & & $\mathrm{I}$ & $\mathrm{OH} \ldots \mathrm{OH}$ & 3418 & 210 & 1.83 & 40.8 & \multirow[b]{2}{*}{52.5} \\
\hline & $\begin{array}{l}\text { Intramolecular } \\
\text { hydrogen bond }\end{array}$ & II & $\begin{array}{l}\text { annular } \\
\text { polymer }\end{array}$ & 3214 & 60.4 & 2.77 & 11.7 & \\
\hline & \multirow{3}{*}{$\begin{array}{l}\text { Intermolecular } \\
\text { hydrogen bond }\end{array}$} & III & $\mathrm{OH} \ldots \pi$ & 3539 & 82.8 & 1.48 & 16.1 & \multirow{3}{*}{47.5} \\
\hline & & IV & OH...ether O & 3298 & 121.6 & 4.23 & 23.6 & \\
\hline & & $\mathrm{V}$ & $\mathrm{OH} . . \mathrm{N}$ & 3125 & 39.9 & 1.02 & 7.8 & \\
\hline \multirow{5}{*}{$\mathrm{PH}=7$} & \multirow[b]{2}{*}{$\begin{array}{l}\text { Intramolecular } \\
\text { hydrogen bond }\end{array}$} & I & $\mathrm{OH} \ldots \mathrm{OH}$ & 3416 & 232.2 & 0.61 & 42.6 & \multirow[b]{2}{*}{53.4} \\
\hline & & II & $\begin{array}{l}\text { annular } \\
\text { polymer }\end{array}$ & 3214 & 59.2 & 2.22 & 10.9 & \\
\hline & \multirow{3}{*}{$\begin{array}{l}\text { Intermolecular } \\
\text { hydrogen bond }\end{array}$} & III & $\mathrm{OH} \ldots \pi$ & 3537 & 92.6 & 1.04 & 17 & \multirow{3}{*}{46.6} \\
\hline & & IV & $\mathrm{OH} \ldots$...ether $\mathrm{O}$ & 3296 & 122.3 & 0.70 & 22.4 & \\
\hline & & V & $\mathrm{OH} \ldots \mathrm{N}$ & 3126 & 38.9 & 2.74 & 7.1 & \\
\hline \multirow{5}{*}{$\mathrm{PH}=8$} & \multirow[b]{2}{*}{$\begin{array}{l}\text { Intramolecular } \\
\text { hydrogen bond }\end{array}$} & I & $\mathrm{OH} \ldots \mathrm{OH}$ & 3418 & 250.1 & 1.00 & 42.2 & \multirow[b]{2}{*}{54.1} \\
\hline & & II & $\begin{array}{l}\text { annular } \\
\text { polymer }\end{array}$ & 3216 & 70.2 & 4.73 & 11.9 & \\
\hline & \multirow{3}{*}{$\begin{array}{l}\text { Intermolecular } \\
\text { hydrogen bond }\end{array}$} & III & $\mathrm{OH} \ldots \pi$ & 3538 & 93.2 & 2.31 & 15.7 & \multirow{3}{*}{45.9} \\
\hline & & IV & OH...ether O & 3298 & 130.7 & 1.79 & 22.1 & \\
\hline & & V & $\mathrm{OH} \ldots \mathrm{N}$ & 3127 & 48.1 & 6.96 & 8.1 & \\
\hline \multirow{5}{*}{$\mathrm{PH}=9$} & \multirow[b]{2}{*}{$\begin{array}{l}\text { Intramolecular } \\
\text { hydrogen bond }\end{array}$} & I & $\mathrm{OH} \ldots \mathrm{OH}$ & 3410 & 87.6 & 3.28 & 30.9 & \multirow[b]{2}{*}{57.8} \\
\hline & & II & $\begin{array}{l}\text { annular } \\
\text { polymer }\end{array}$ & 3202 & 76.2 & 2.33 & 26.9 & \\
\hline & \multirow{3}{*}{$\begin{array}{l}\text { Intermolecular } \\
\text { hydrogen bond }\end{array}$} & III & $\mathrm{OH} \ldots \pi$ & 3531 & 70 & $0 . .66$ & 24.7 & \multirow{3}{*}{42.2} \\
\hline & & IV & $\mathrm{OH} \ldots$...ether $\mathrm{O}$ & 3298 & 48.2 & 6.26 & 17 & \\
\hline & & $\mathrm{V}$ & $\mathrm{OH} \ldots \mathrm{N}$ & 3164 & 1.52 & 7.81 & 0.5 & \\
\hline
\end{tabular}


Table 3. The EDX element analysis data of spectrum 1

\begin{tabular}{cccccccc}
\hline Element & $\mathrm{C} \mathrm{K}$ & $\mathrm{OKK}$ & $\mathrm{Na} \mathrm{K}$ & $\mathrm{S} \mathrm{K}$ & $\mathrm{Cl} \mathrm{K}$ & $\mathrm{Ca} \mathrm{K}$ & $\mathrm{Pt} \mathrm{M}$ \\
\hline Weight $/ \%$ & 45.89 & 25.7 & 14.69 & 1.05 & 8.38 & 0.46 & 2.95 \\
Atomic $/ \%$ & 59.97 & 25.21 & 10.03 & 0.51 & 3.71 & 0.18 & 0.24 \\
\hline
\end{tabular}


Table 4. The EDX element analysis data of spectrum 2

\begin{tabular}{cccccccc}
\hline Element & C K & O K & Na K & S K & Cl K & Ca K & Pt M \\
\hline Weight $/ \%$ & 40.41 & 34.57 & 14.22 & 0.76 & 6.35 & 0.33 & 3.37 \\
Atomic $/ \%$ & 52.8 & 33.91 & 9.71 & 0.37 & 2.81 & 0.13 & 0.27 \\
\hline
\end{tabular}




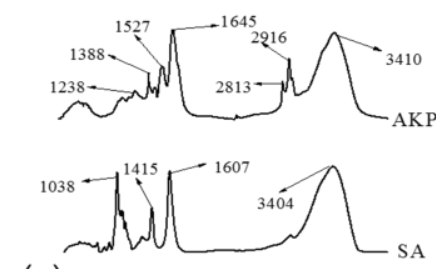

(a)
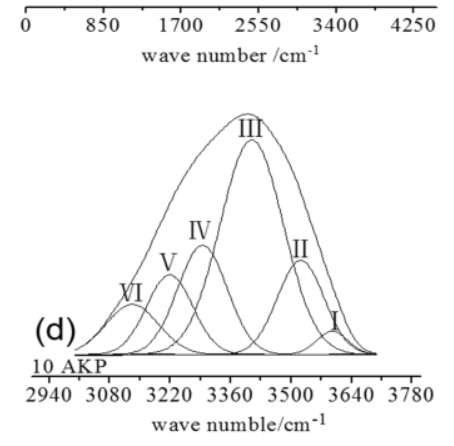
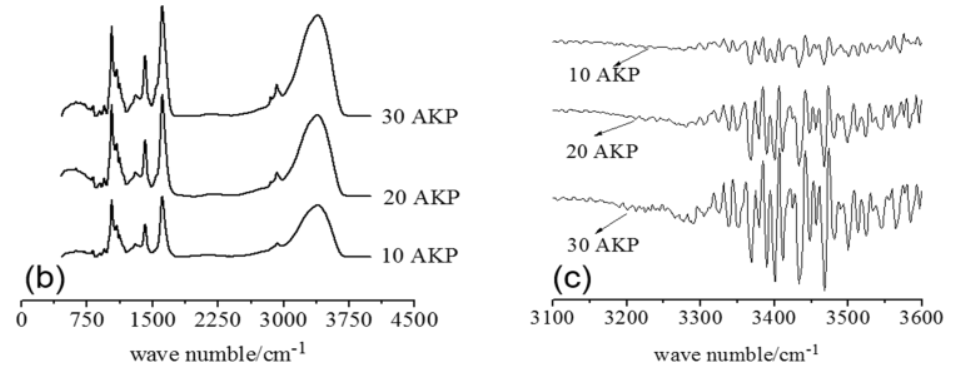

(e)

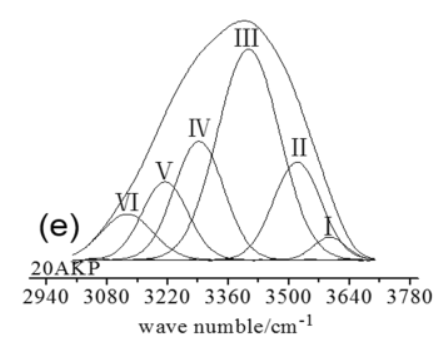

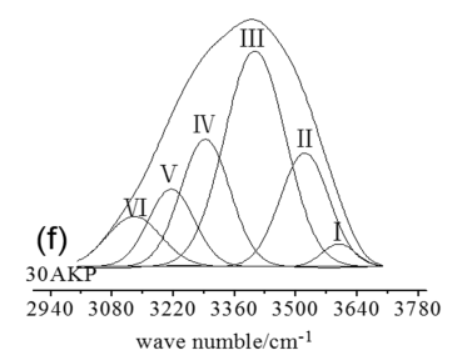
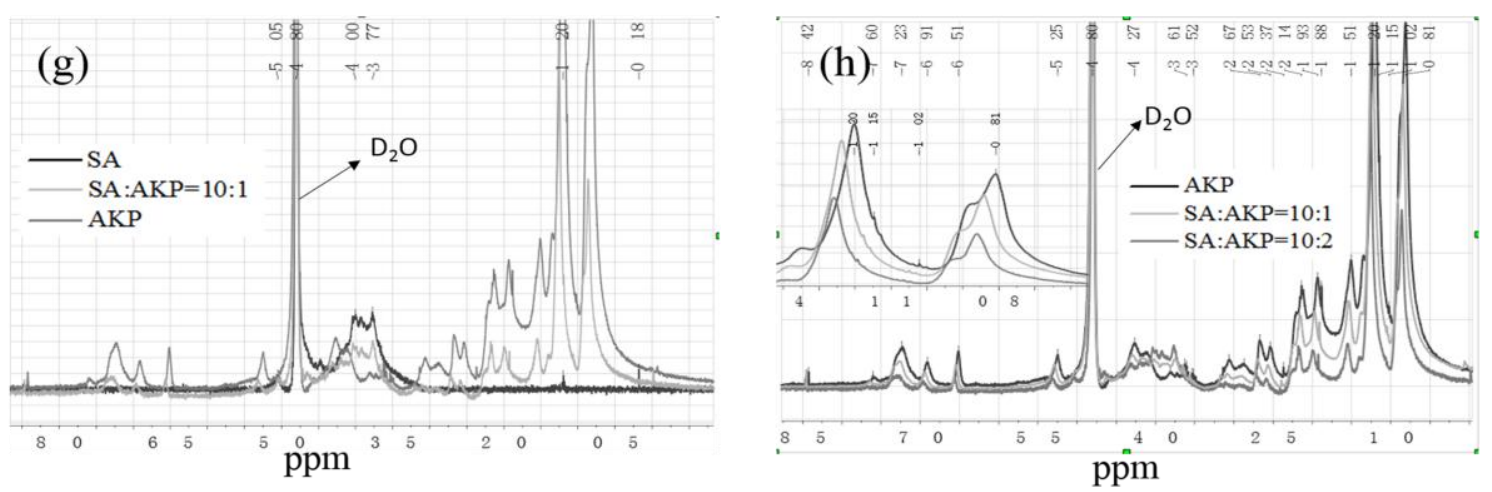

Fig. 1 Infrared spectra of (a) pure SA and AKP and (b) composite material with different content of AKP (w/w: 10/1, 10/2, 10/3 for $10 \mathrm{AKP}, 20 \mathrm{AKP}, 30 \mathrm{AKP})$ ), (c) the second derivative spectra of composite material, Gauss curve fitting of composite material by different types of hydrogen bonds at different content of AKP (d) 10/1, (e) 10/2, (f) 10/3, (g) and (f) HNMR of SA/AKP composite. 

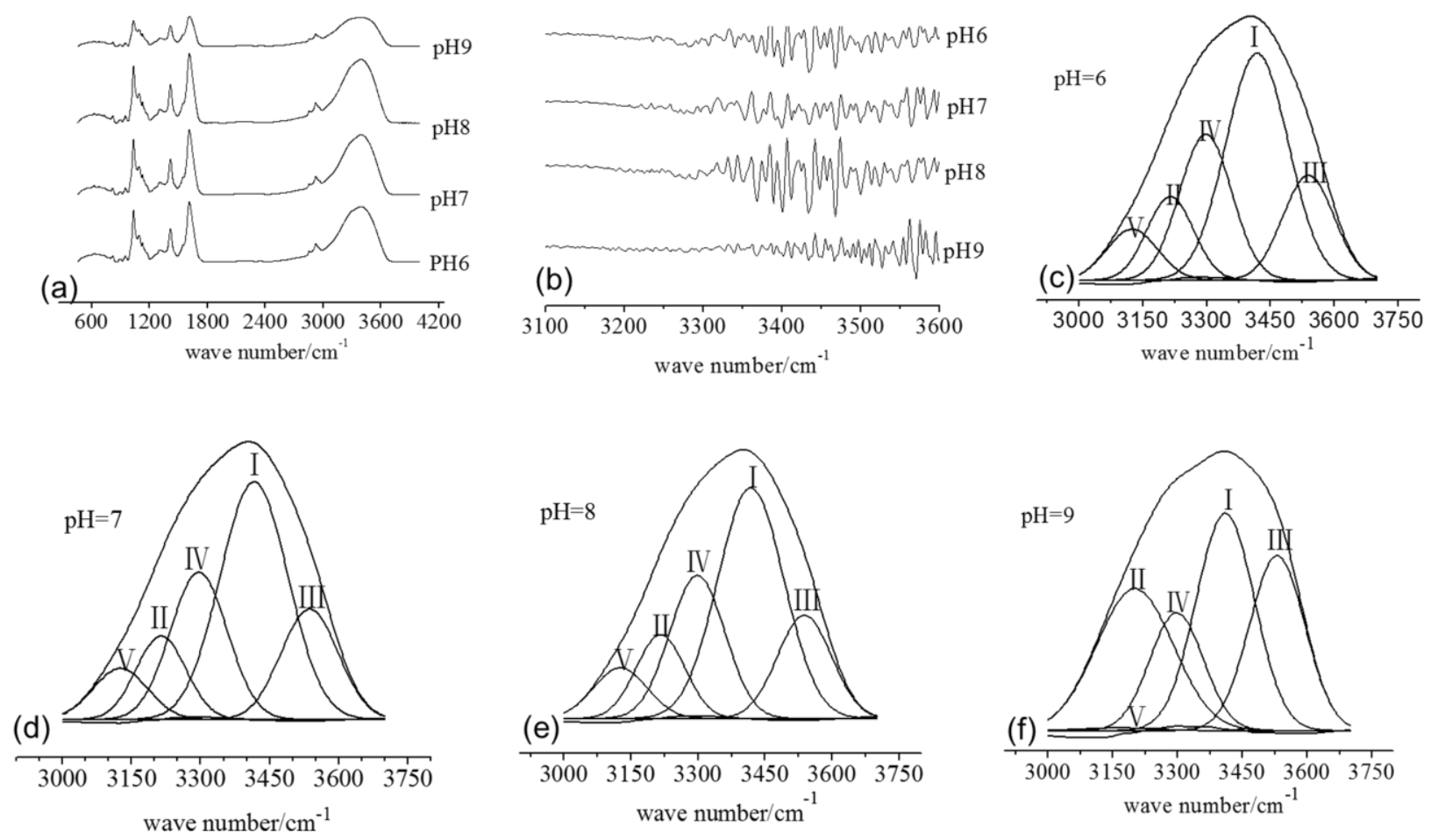

Fig. 2 Infrared spectra (a), the second derivative spectra (b) and Gauss curve fitting by hydrogen bonds of composite material at different $\mathrm{pH}$ (c) $\mathrm{pH}=6$, (d) $\mathrm{pH}=7$, (e) $\mathrm{pH}=8$, (f) $\mathrm{pH}=9$. 

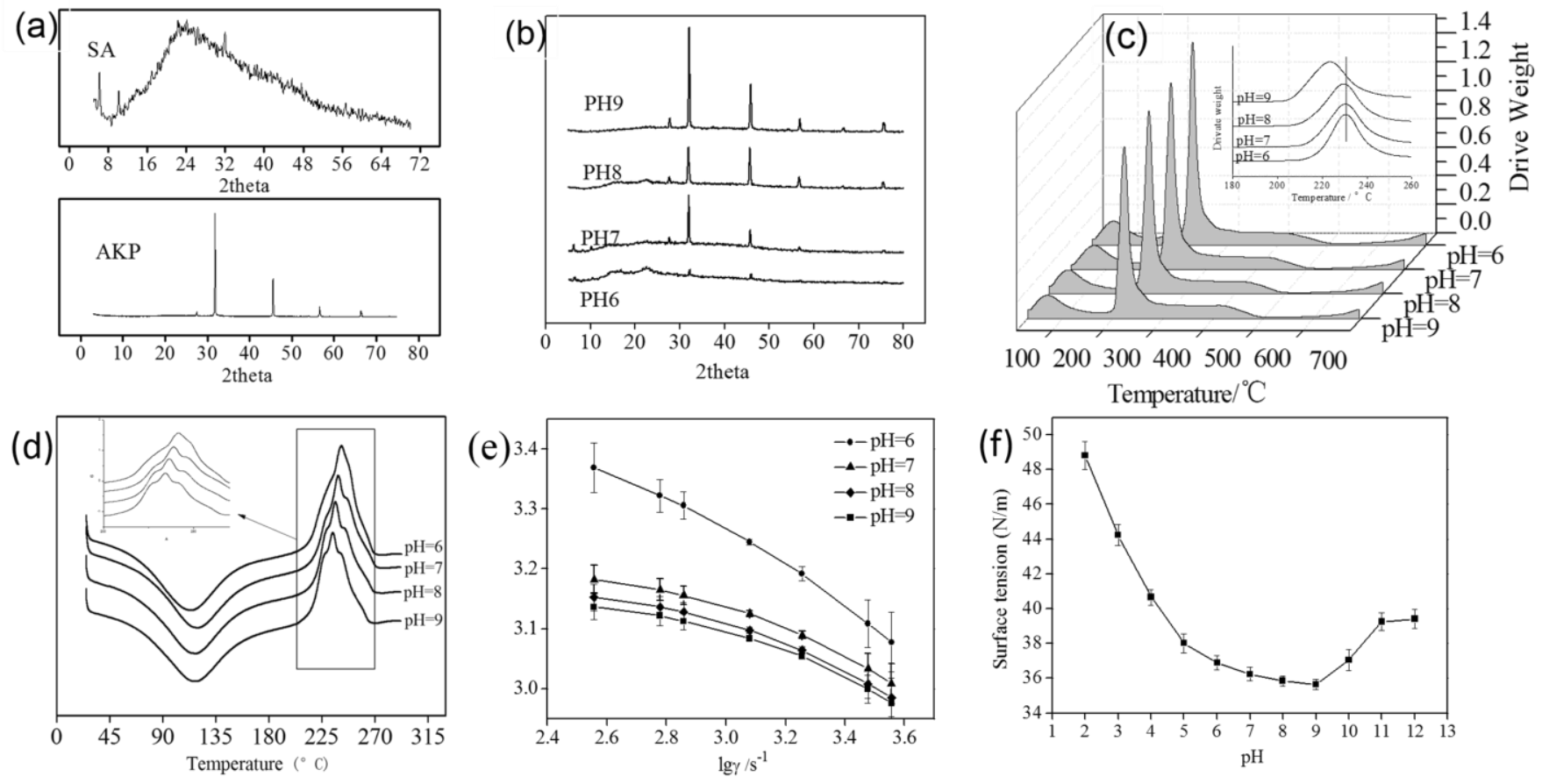

Fig. 3 XRD curve of SA and APK (a ) and SA/AKP composite material at different pH (b), The thermal degradation of derivative curve of the SA/AKP composite at different $\mathrm{pH}(\mathrm{c})$, DSC curve of the SA/AKP composite at different $\mathrm{pH}(\mathrm{d})$, The effect of $\mathrm{pH}$ on viscosity of composite material (e), The effect of $\mathrm{pH}$ on viscosity of Surface tension (f). 

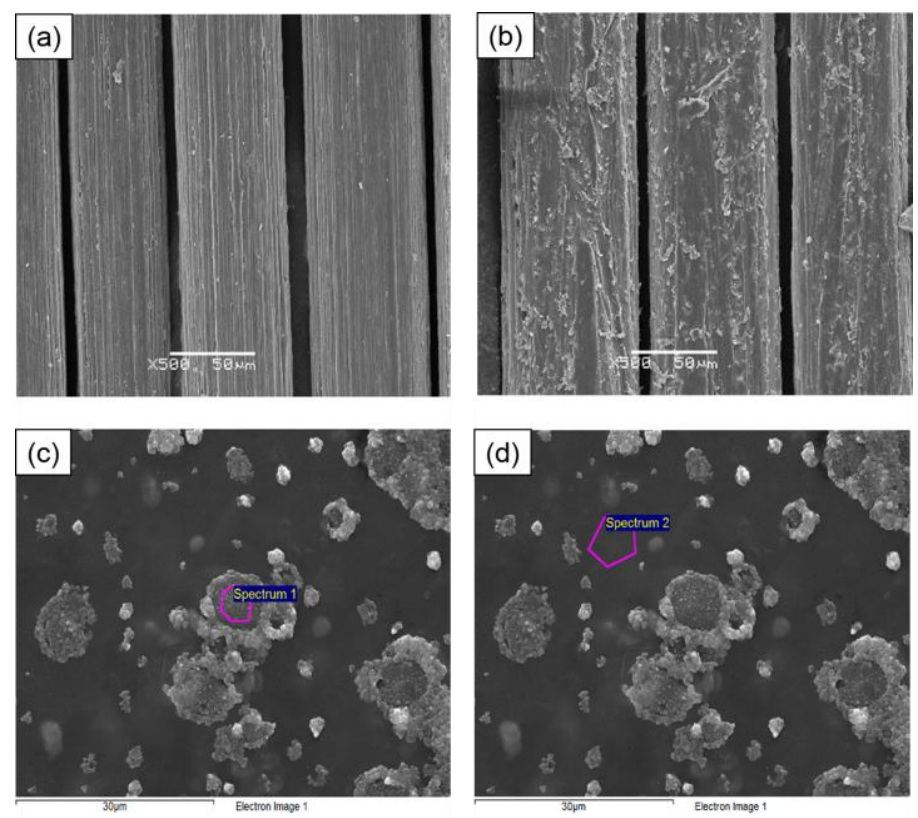

Fig. 4 The SEM images of no friction of the fiber (a) and friction of the fiber (d), EDX of SA/AKP composite fiber (c \& h). 